\title{
Entre família e Nação: a filiação naturalizada ${ }^{1}$
}

Between Family and Nation: The naturalization of filiation

Entre familia y nación: la naturalización de la filiación

\author{
Éric Fassin \\ Universidade Paris VIII, Paris, França \\ Tradução: Henrique Caetano Nardi
}

\section{Resumo}

Na França, o debate sobre as uniões de casais do mesmo sexo foi mais centrado na filiação ao mesmo tempo naturalizada e sacralizada - do que no casamento, como foi o caso dos Estados Unidos. A filiação não é mais definida pelo casamento, mas em termos biológicos. Nós podemos certamente compreender este fato como uma reação contrária às novas reivindicações relativas ao "casamento gay", mas também como parte dos debates sobre a nacionalidade francesa, no contexto das políticas anti-imigração. De fato, a filiação pertence tanto ao direito de família como ao direito de nacionalidade, intersecção crucial nos casamentos binacionais. Além disso, a diferença legal entre as famílias francesas e estrangeiras é cada vez mais definida em termos biológicos a partir de um "DNA francês", contribuindo assim para uma racialização da nação.

Palavras-chave: Família, Imigração, Nação, Racialização.

\begin{abstract}
Contrary to the United States, the debate on same-sex unions in France has focused not on marriage, but on "filiation", simultaneously naturalized and sacralized. Filiation is no longer defined by marriage, but rather in biological terms. While this can be read as a reaction against the new politics of "gay marriage", it can also be interpreted in the context of debates about French citizenship, i. e., against the backdrop of anti-immigrant politics and policies. Filiation belongs both to family law and citizenship law and this intersection becomes crucial in the case of binational marriages. More broadly, the legal difference between French and foreign families is increasingly defined in the biological terms of a "French DNA", thus contributing to a racialization of the nation.
\end{abstract}

Keywords: Family, Filiation, Immigration, Nation, Racialization. 


\section{Resumen}

Al contrario del ejemplo estadounidense, el debate sobre las uniones de personas del mismo sexo en Francia no se centra en el matrimonio, pero en la "filiación", esta simultáneamente naturalizada y sacralizada. El concepto de filiación ya no puede ser solamente definido a través del matrimonio, sino más bien en términos biológicos. Por un lado, este hecho puede ser entendido como una reacción contra la nueva política de los "matrimonios gays"; por otro lado, puede ser interpretado también en el contexto de los debates sobre la ciudadanía francesa, es decir, en el entorno de las políticas anti-inmigración. Filiación pertenece tanto al derecho de familia como al derecho de ciudadanía, así que, esta intercesión pasa a ser crucial en caso de los matrimonios binacionales. En términos más generales, la diferencia legal entre las familias francesas y las familias extranjeras está siendo cada vez más definida en términos biológicos de lo que llamamos un "DNA francés"; contribuyendo de este modo a la racialización de la nación.

Palabras llave: Familia, Filiación, Inmigración, Nación, Racializatión.

Frédéric Minville foi destituído da nacionalidade francesa em dezembro de 2007. Isso porque, residente na Holanda desde 2002 e casado com um holandês desde 2003, ele tinha assumido a nacionalidade de seu marido em 2006. Claro, um acordo entre os dois países autoriza seus cidadãos a escolher a dupla nacionalidade nos casos de casamentos binacionais; entretanto, a França não reconhece o casamento de casais do mesmo sexo, existente na Holanda desde 2001. Essa foi a razão pela qual o consulado francês, após consultar o ministério das relações internacionais, pediu que ele devolvesse sua carteira de identidade francesa e seu passaporte. Sem dúvida, em consequência da mobilização midiática, associativa e política contra aquilo que era entendido por muitos como uma forma de discriminação, Frédéric Minville deverá recuperar sua nacionalidade de origem a partir de julho de 2008. Essa querela trouxe à tona uma relação até agora quase invisível entre o que se convencionou chamar de “casamento gay" e a nacionalidade ${ }^{2}$.

\section{A Filiação Sacralizada}

É a articulação política entre estas duas questões jurídicas [filiação e nacionalidade] que propomos examinar aqui, focando na especificidade do contexto atual francês. De fato, a comparação transatlântica permite fazer aparecer uma diferença crucial entre os debates políticos norte americano e 
francês: enquanto nos Estados Unidos é o casamento em si mesmo que está no centro da batalha política, na França a questão central é a filiação. Do outro lado do Atlântico, a oposição às reivindicações homossexuais não se mobiliza contra o acesso à adoção, e ainda menos contra a reprodução assistida. $\mathrm{Na}$ França é totalmente o contrário: muitos (antes de esquerda e hoje de direita) estariam dispostos a conceder aos homossexuais um estatuto conjugal desde que amputado de todo direito relativo a esta questão - ou seja, um casamento sem filiação. Existe, portanto, um contraste claro transatlântico: a sacralização é colocada sobre o casamento nos Estados Unidos e, na França, sobre a filiação ${ }^{3}$. A expressão não é de forma alguma metafórica: o que se sacraliza, em uma sociedade democrática, é aquilo que se estima essencial e que se busca, então, retirar da esfera da deliberação política para conceder o estatuto de verdade absoluta que transcende a história.

O caso Minville não questiona esta tese: de fato, é precisamente porque se trata somente de conjugalidade, e não de filiação, que o Estado Francês pôde rever sua decisão tão rapidamente. Para nos convencermos, basta comparar a destacada reatividade ao caso Minville com o silêncio dos poderes públicos quando, em janeiro de 2009, o Conselho Geral do Jura [região do leste da França] recusou pela segunda vez a autorização para a adoção de uma criança por Emmanuelle B, a despeito dos pareceres favoráveis da assistente social e da psicóloga. Embora ela estivesse vivendo de forma conjugal com uma mulher, é claro que ela fez a demanda de adoção individualmente, pois a adoção conjunta é reservada aos casais casados; entretanto, é evidente que foi sua conjugalidade homossexual que foi questionada, uma vez que o lugar de sua companheira em relação à adoção foi julgado "ambíguo". Contudo, após longos dez anos de julgamento, um ano antes da sentença não tinha a França sido condenada, neste mesmo processo, pela Corte Europeia dos Direitos Humanos ${ }^{4}$ ? Evidentemente, como pudemos constatar quando se abriram os debates a respeito do "contrato de união social" em 1997, o casamento homossexual não foi considerado um problema na França, desde que ele não abrisse a porta para a filiação.

Um editorial da revista Elle, ironizando a indignação suscitada pelo caso de Frédéric Minville, confirma esta constatação (Werner, 2008, 12): “Se nos apressarmos, é verdade, isso parece escandaloso." Entretanto, "é a lei sobre as duplas nacionalidades, e ela não tem nada a ver com o fato de preferir mulheres ou homens". A editorialista não para por aí: não será porque se quer "a todo custo 
introduzir no debate a questão do casamento homossexual"? $\mathrm{Ou}$, "lembremos que esta legislação se choca com um obstáculo muito simples, objetivo e, cabe ressaltar, perfeitamente aceito pela maioria silenciosa dos homossexuais na França: mesmo que possamos rediscutir sua função, o casamento é, juridicamente e simbolicamente, a instituição que garante a filiação, o lugar de cada um em uma genealogia. Afinal, para dar a luz a uma criança, necessita-se de uma pessoa do sexo masculino e outra do sexo feminino. Hoje, tudo nos leva a esquecer desta constatação antropológica básica!” É evidente, portanto, que "não se trata de uma discriminação anti-gay!"”.

\section{A Naturalização da Filiação}

Algo que é desenvolvido, às vezes, de maneira mais sofisticada é aqui enunciado de forma crua: a filiação é confundida com a reprodução e o caráter imutável da biologia torna-se uma verdade inquestionável para a antropologia. Dito de outra forma, a sacralização da filiação é inseparável de sua naturalização. Para se compreender a importância da primeira questão, é indispensável retornar à segunda - ou seja, retomar a tipologia proposta por Daniel Borrillo quando este aponta a união civil como um "PaCS ${ }^{5}$ da filiação", ao indicar que o modelo "civilista" de filiação cede terreno hoje na França a um paradigma, se não "canônico", pelo menos, "neobiológico" (Borrillo, 2009). Como interpretar esta re-naturalização ou, mais precisamente, uma biologização da filiação que se tornou tão visível no debate francês sobre as uniões de casais do mesmo sexo?

Ao instituir a igualdade entre a filiação natural e a filiação legítima, a lei de 1972 renunciou a colocar o casamento como princípio da filiação; apesar disso, ela [a lei] não definiu claramente um fundamento novo que o substituiria. Foi somente nos anos 1980 que o modelo biológico pouco a pouco se impôs, até se tornar predominante - em particular por ocasião da promulgação das leis ditas da bioética em 1994. Sabemos que a reprodução assistida é reservada pelo legislador aos casais estéreis, casados ou não, mas formados por um homem e uma mulher em idade fértil: a filiação é assim colada à reprodução. Esta superposição não é nada evidente: o naturalismo biológico foi instituído na filiação como que para nos fazer esquecer que a introdução da tecnologia na reprodução é, de fato, a imagem e o espelho do direito à adoção e que lei de 1966, ao autorizar a adoção pelos solteiros, tinha confirmado o artificialismo $^{6}$ da filiação.

Sabemos também que a pretensa naturalidade da filiação será questionada a partir do fim dos anos 1990 pelas 
reivindicações dos casais do mesmo sexo que começavam a se fazer escutar nos temas referentes ao 'casamento gay' e à 'homoparentalidade'. Podemos então nos perguntar: a cronologia não nos convida a reverter a lógica? A consequência não poderia finalmente ser uma causa? Como lembrou ainda Daniel Borrillo, "até os anos 1990, o conjunto de especialistas do direito de família estava de acordo sobre a dimensão eminentemente social e cultural da filiação (modelo civilista), entretanto, quando uma reivindicação homoparental começa a surgir na cena pública, uma redefinição de tipo naturalista começa a vir a tona"7. Dito de outra maneira, tudo se passa como se a biologização da filiação intervisse justamente para fornecer argumentos que justificam a limitação dos direitos dos homossexuais, sem, ao mesmo tempo, levantar a suspeita de homofobia.

De fato, existem razões para dar crédito a esta hipótese. Nos debates em torno do PaCS, e além do PaCS, e em resposta à invocação pelos adversários do PaCS de uma diferença de sexos que deveria definir os "fundamentos antropológicos" da filiação, era fácil aos partidários [do PaCS] de lembrar o exemplo da adoção pelos solteiros: não é esta a prova de que coexistem no direito francês regimes de filiação distintos? E de se opor à "ilusão antropológica" segundo a qual "a" cultura - ou somente "a nossa cultura" - determinaria verdades atemporais, a ideia de que a ordem simbólica da filiação é histórica, isto é, que se trata de uma ordem definida por escolhas políticas. Em resumo, não se trata de uma Lei transcendental de uma antropologia "dogmática", mas das leis imanentes à democracia? Nós vimos a União Nacional das Associações de Família (UNAF) reconhecer as consequências desta objeção ${ }^{8}$. Assim, para sustentar a recusa de adoção aos homossexuais, sem se ver taxada de discriminação homofóbica, não seria melhor renunciar à adoção individual qualquer que seja a orientação sexual? Desta forma, a diferença de sexos se tornaria o fundamento antropológico da filiação da qual ela deveria, desde sempre, ter sido.

\section{Direito de Família e Direito de Nacionalidade}

Gostaríamos de propor aqui outra interpretação para o crescimento do modelo naturalista da filiação na sociedade francesa. Ao invés de demarcar como ponto de partida a questão homossexual, podemos nos perguntar sobre a questão da filiação em si - e não somente sobre a naturalização. Por que a filiação adquiriu tal importância no debate público na França? Proporemos aqui a hipótese de que 
é nos debates em torno da nacionalidade que devemos procurar a resposta. É importante inicialmente lembrar que no código civil a filiação não está relacionada somente ao direito de família; ela está igualmente no centro do direito de nacionalidade. No capítulo primeiro, que trata "das pessoas", a filiação contribui para definir (no parágrafo $1^{\circ}$ bis) “a nacionalidade francesa de origem" (artigo 18); e, em seguida, “a aquisição da nacionalidade francesa" (artigo 21), bem antes de ser definida (nos parágrafos VII e VIII) no seio da família (artigos 310 a 370). É mais relevante levar em conta essa segunda interpretação (nacional), do que a primeira (familiar), se buscamos aqui compreender a especificidade nacional francesa da naturalização da família.

É na segunda metade dos anos 1980 que se retoma o debate sobre o direito de nacionalidade na França - no momento em que se dá forma à resposta "republicana" às inquietudes sobre a nação. Neste contexto, o crescimento do Front National ${ }^{9}$ é emblemático, ou seja, é ao mesmo tempo sintoma e catalisador. O que é ser francês? Como Patrick Weil bem demonstrou, é um erro opor duas culturas políticas da nação uma francesa, definida pela cidadania eletiva; e outra, alemã, definida por uma cidadania étnica. $\mathrm{Na}$ verdade, o equilíbrio entre jus soli e jus sanguinis é uma questão política tensa e não resolvida que atravessa a história da nacionalidade francesa (Weil, 2002). Ele [o equilíbrio] está no centro das reflexões que animaram os projetos de reforma da nacionalidade discutidos pela comissão Marceau Long a partir de 1987 e endurecidos na lei de 1993. Devemos considerar que a partir deste momento, a despeito da invocação de uma nação eletiva cara a Renan, pouco a pouco, o direito do sangue foi se reforçando em detrimento do direito de solo. Dito de outra forma, podemos falar de uma lógica de naturalização da nacionalidade em construção há uns vinte anos, definida, hoje, mais pela filiação que anteriormente - ou seja, uma nova "crise étnica" da nacionalidade francesa.

Em 2002, em reposta à pergunta “como nos tornamos franceses?" Patrick Weil evocava "dois procedimentos altamente abertos": "o casamento" e "o nascimento na França". Logo após este momento, assiste-se - em um contexto político de combate à imigração familiar dita "imposta" (contrastando com a imigração pelo trabalho, supostamente “escolhida") - a um controle cada vez mais forte da filiação nacional sobre duas situações complementares: por um lado, os casamentos mistos e, pelo outro, o reagrupamento familiar. Essas duas formas de limitar a imigração tem efeitos estendidos mecanicamente sobre a aquisição da nacionalidade. Assim, 
restringir a imigração familiar é, na prática, reforçar o peso da filiação e, portanto, do sangue, na definição da nacionalidade ${ }^{10}$.

Esta desconfiança institucionalizada se exerce em primeiro lugar quanto aos casamentos binacionais, suspeitos a priori de serem "casamentos de fachada": seu número não dobrou entre 1995 e 2003, até se constituírem, hoje, em um terço dos casamentos na França? Poderíamos ter nos dado conta dessa questão quando dos debates preparatórios da lei sobre o controle da validade dos casamentos, apresentada pelo Ministro da Justiça Pascal Clément, em 2006. Esta lei só pode ser entendida como um apêndice da lei sobre a imigração defendida no mesmo ano por Nicolas Sarkozy, então Ministro do Interior. Assistimos, assim, a instituição pela lei, e não somente pelos procedimentos burocráticos, do que eu e Daniel Borrillo tínhamos qualificado de “chauvinismo matrimonial". De fato, é o sangue nacional que se trata de preservar com o acesso ao casamento (Borrillo \& Fassin, 2006, maio 16).

O segundo aspecto desta política de controle visando a restringir a imigração "imposta" diz respeito ao reagrupamento familiar. Sabemos que na França este direito é cada vez menos incondicional: a vida familiar toma assim um sentido diferente se se trata de famílias francesas ou estrangeiras. Por exemplo, vimos que, desde julho de 2008, a proteção subsidiária acordada pela OFPRA (Departamento Francês para a proteção de refugiados e expatriados) às filhas de imigrantes, cujo retorno ao país de origem incorreria no risco de mutilações genitais, não se estendia a suas mães quando estas já tivessem sofrido tal mutilação. Até a suspensão desta decisão pela Corte Nacional de Direito de Asilo (CNDA), em 12 de março de 2009, era possível, portanto, expulsar a mãe sem sua filha. As demandantes de asilo da África do Oeste só seriam notificadas pela OFPRA quando, em caso de expulsão, elas fizessem a escolha de levar suas filhas com elas. Expondo as mães desta forma, não se tornariam elas as únicas responsáveis pelas eventuais mutilações em suas filhas?

Chegar a esta constatação não é suficiente. É importante ainda ressaltar que a diferença entre a família nacional e estrangeira é, hoje, literalmente biologizada. Foi o que se pode constatar com a adoção controversa do adendo à lei da imigração de 2007 que propôs o recurso aos testes de DNA para superar as supostas carências de informação referentes ao estado civil em alguns países e, assim, estabelecer a certeza quanto à filiação das crianças quando das demandas de reagrupamento familiar. Este adendo significava que a filiação dos estrangeiros deveria ser verificada a partir da biologia, 
ou seja, um laço de sangue que enfatiza a precaução finalmente retida de não se levar em consideração o DNA paterno ${ }^{11}$. Ou seja, é definir pelo avesso, a partir do DNA dos imigrantes, o DNA nacional.

$$
\text { É notável que o Conselho }
$$
Constitucional, em sua decisão de 15 de novembro de 2007 ( $\mathrm{n}^{\circ} 2007-557$ DC), tenha validado este adendo $\left(\mathrm{n}^{\circ} 13\right)$ e, sobretudo, que ele o fez ao mesmo tempo em que julgava contrário à Constituição o adendo (n63) que autorizava as estatísticas ditas "étnico-raciais" - sem dúvida o argumento foi técnico (se tratava de um artigo da lei que introduzia disposições que não se relacionavam ao objeto do projeto de $1 \mathrm{i}^{12}$ ), mas também por razões de princípio (seria contrário ao artigo primeiro da Constituição). Dito de outra forma, os Sábios proíbem a introdução de distinções de raça na população francesa, mas autorizam a biologização dos estrangeiros. Não se tratava, portanto, de sugerir que para preservar a filiação nacional é lícito racializar os imigrantes?

\section{O DNA Francês}

Enganar-nos-íamos em acreditar que a biologização da filiação, presente na política atual de imigração, não teria relação com a naturalização da filiação que encontramos nos debates sobre a homoparentalidade. A política do sangue que atravessa as leis da filiação atinge tanto a família como a nacionalidade. A invocação da diferença de sexos como fundamento antropológico da (ou da nossa) cultura, tradução retórica e mesmo teórica do movimento jurídico de naturalização da família, não poderia ser compreendida somente como reação às reivindicações dos homossexuais, ela se inscreve igualmente na continuidade da virada política iniciada nos anos 1980, cujas consequências ainda não foram completamente percebidas, mas que nos levou até este momento a uma naturalização da nação. Novamente, o contraste com os Estados Unidos é esclarecedor, em um país onde a filiação não foi objeto de sacralização no debate sobre o casamento, diferentemente da França, é bem o jus solis que continua a definir a nacionalidade.

O mais impressionante, é que nós não percebemos antes a ligação entre estas duas lógicas, familiar e nacional, mesmo que, como vimos, a filiação pertence a estes dois registros no código civil francês. Sem dúvida a divisão do trabalho, não somente no campo universitário, mas também no mundo associativo, político e mediático, explica esta cegueira. As categorias que organizam os saberes das ciências sociais, mas também o conjunto dos discursos sobre a sociedade, 
distinguem família e nação como duas paralelas que nunca deveriam se cruzar. Ainda há mais. Se a articulação entre família e nação não emergiu até agora nas reflexões sobre os "fundamentos antropológicos", é também porque seu sentido político foi somente esboçado; ou seja, foi o desenrolar atual das implicações dessa naturalização que o tornaram aparente.

Tomemos a pesquisa de Paul Rabinow, especialista em antropologia da ciência, sobre o "mapeamento do genoma" (Rabinow, 2000). A história do mapeamento do genoma humano foi retraçada pelo autor a partir da intervenção do Estado Francês que, em 1994, impediu uma cooperação entre um grande laboratório francês e uma empresa start up norte americana do domínio da biotecnologia. Não temia o governo que nossos pesquisadores estavam prestes a "entregar aos Norte Americanos o bem mais precioso - algo que nunca tinha ainda recebido tal denominação - o DNA francês"? Esta formulação presente no título do livro de Rabinow na sua versão original desapareceu na tradução francesa: é que antes da "emenda DNA", não tínhamos percebido todo seu sentido. Retrospectivamente, a nacionalização do DNA se compreende a luz das leis ditas da bioética, adotadas em 1994, que tratam das regras da reprodução, mas também da reforma da nacionalidade votada em 1993 que, paralelamente, contribui a naturalizar a filiação nacional. Assim, quando o livro é publicado na virada dos anos 2000, não se reconhecia ainda a precisão de uma citação que fazia o elogio do livro na capa da edição norte americana: "Quem pensaria que poderia existir um Código Napoleão Genético?”.

\section{A Família Nacional}

O crescimento da força do direito do sangue, em relação à nacionalidade, contribuiu para a construção de uma representação naturalizada dos laços de filiação que deveria ter sido invocada quando dos debates em torno do Pacto Civil de Solidariedade. Assim, não é um acaso que, desde 1999, o PaCS tenha direitos restritos se comparado ao casamento, essencialmente em dois pontos: por um lado, os direitos relacionados à filiação e, pelo outro, os direitos dos casais binacionais, seja em relação à família como a nacionalidade ${ }^{13}$. É no campo da Democracia Sexual, que por sinal todos reivindicam hoje, a começar pelo Presidente da República [Francesa, no caso, o ex-presidente Nicolas Sarkosy], que a questão da filiação, sacralizada por excelência e subtraída da deliberação política que a filiação foi constituída em "fundamento antropológico" de nossa 
cultura nacional e, portanto - em todos os sentidos do termo - naturalizada.

Também não é, portanto, por acaso, que a situação dos casais ditos "mistos" tenha sido objeto de uma mobilização pelos direitos dos casais do mesmo sexo capitaneada pela ARDHIS - Associação pelo Reconhecimento dos Direitos de Pessoas Homossexuais e Transexuais à Imigração e à Permanência, nascida justamente em 1998, em pleno debate sobre o PaCS - fruto do cruzamento de dois movimentos políticos: o primeiro, pelo reconhecimento dos casais do mesmo sexo e; o segundo, pelo reconhecimento dos sans papiers ${ }^{14}$. Cabe lembrar que foi somente dez anos mais tarde, em 2008, que a articulação política entre conjugalidade e migração será reivindicada por uma associação que se ocupa dos casais heterossexuais: se trata de "Amoureux au ban public ${ }^{15,}$, Ou seja, a questão homossexual teria sido a reveladora da naturalização da filiação nacional, bem antes que se percebessem seus efeitos colaterais sobre os casais de sexos diferentes (Fassin, 2008).

$\mathrm{O}$ argumento proposto aqui referese, claro, à homossexualidade e, obviamente, a França de hoje. Entretanto, gostaríamos de sugerir que ele ultrapassa ambos os contextos. Tomemos um só exemplo, no trabalho de Susan Martha Kahn sobre os debates referentes à reprodução assistida em Israel, nos anos 1990: eles se deram em um contexto político que fez da natalidade uma questão se segurança nacional. Foi neste contexto que o Estado subvenciona os centros de reprodução assistida e paga os tratamentos contra a infertilidade mesmo para as mulheres solteiras. Israel foi o país que primeiro reconheceu as maternidades de substituição [barrigas de aluguel] e que conta com as taxas mais altas do mundo de fecundação in vitro. A antropóloga mostra como os rabinos ortodoxos tiveram de encontrar uma solução permitindo o dom de esperma, incompatível com as proibições religiosas referentes à masturbação, e também ao adultério: bastou recorrer ao esperma de não judeus e as proibições sexuais caíram por terra. Se disséssemos que se trata de uma maneira paradoxal de contribuir a "reproduzir os judeus", esqueceríamos que, para o judaísmo, é a mãe que transmite a filiação. Foi desta forma que puderam ser legitimados - ao preço de um atalho sem dúvida desconcertante - estes "filhos de Israel" (Kahn, 2007).

Como vemos, a articulação entre filiação familiar e filiação nacional não é restrita nem à homossexualidade, nem a França: ela se estende tanto aos heterossexuais como afeta os espaços nacionais. É que entre família e nação - a filosofia política sabe há muito tempo, mas 
esquecemos muito frequentemente no fogo das controvérsias contemporâneas - que se definem as sociedades modernas. Todavia, o que se buscou mostrar nestas páginas e que não é o simples resgate de uma história consagrada desde muito tempo, é que a naturalização da filiação que se coloca em prática hoje na França - e da qual tomamos consciência por ocasião dos debates sobre o reconhecimento dos casais de mesmo sexo - é precisamente o inverso da lógica da democracia sexual: se neste regime que caracteriza hoje nossas sociedades, as normas se revelam pelo que são, isto é, construções inseparavelmente históricas e políticas, então as tentativas de naturalização da filiação devem ser entendidas como um esforço propriamente reacionário de subtrair a família nacional da lógica de desnaturalização.

\section{Notas}

${ }^{1}$ Artigo traduzido por Henrique Caetano Nardi com autorização do autor. Publicado originalmente em francês como: Fassin, E. (2009) Entre famille et nation: la filiation naturalisée. Droit et Société, 72, 373-382.

${ }^{2}$ Sobre esta relação, ver Fassin, E. (2008) L'amour du même et l'amour de l'autre: le 'mariage homosexuel' entre famille nationale et question raciale (FranceEtats-Unis) In V. Descourtes, M. Digoix, E. Fassin, \& W. Rault (orgs.) Mariages et homosexualités dans le monde.
L'arrangement des normes familiales (pp. 96-108). Paris: édition Autrement.

${ }^{3}$ Encontraremos uma primeira formulação deste argumento em meu artigo: Fassin, E. (2001) Same Sex, Different Politics: comparing and contrasting 'gay marriage' debates in France and the United States. Public Culture, 13(2), 215-232. Ele foi desenvolvido em Fassin, E. (2006) Du sacré dans les sociétés démocratiques: le mariage aux États-Unis, la filiation en France In A. Cadoret, M. Gros, C. Mecary, \& B. Perrau (dir.) Homoparentalités. Approches scientifiques et politiques (pp. 535-362). Paris: PUF.

${ }^{4}$ Encontra-se, além de uma entrevista com Emmanuelle B., uma descrição precisa deste caso na nova mídia gay e lésbica on line, $\quad$ Yagg: http://yagg.typepad.com/yagg/2009/02/ado ption-la-demande-deemmanuelle-et-delaurence-a-nouveau-rejetee-par-le-conseilgeneral-du-jura-777.html

${ }^{5}$ Nota do tradutor: PaCS é a sigla de Pacto Civil de Solidariedade, nome dado ao contrato de união estável aberto a casais do mesmo sexo na França.

${ }^{6}$ Sobre os dois modelos de filiação que propõe o direito de adoção e aquele da reprodução assistida, ver Fassin, E. (1998) L'illusion anthropologique: homosexualité et filiation, Témoin, 12 (dossier "Famille, nouvelles unions, bonheur privé et cohésion sociale (pp. 43-56); ver 
igualmente, a crítica forte do naturalismo das leis de bioética em Iacub, M. (2003) Le crime était presque sexuel, et autres essais de casuistique juridique. Paris: Flammarion.

7 Borrillo, D. (2010) La parenté et la parentalité dans le droit : conflits entre le modèle civiliste et l'idéologie naturaliste de la filiação, conferência pronunciada na Biblioteca Pública da Informação (BPI) quando do colóquio "Des femmes et des hommes : parenté et parentalité" do qual eu (com Elsa Dorlin) assumi a organização científica em novembro de 2007 (anais publicados pelas Edições BPI em 2010).

$8 \mathrm{Eu}$ pude medir o impacto deste argumento por tê-lo utilizado quando de um debate organizado em dezembro de 1998 pela UNAF (e o CEDIAS): "Les implicites de la politique familiale de demain”. Esta intervenção foi em seguida publicada em uma coletânea: Fassin, E. (2000) La Famille 'naturalisée' In M. Chauvuère, M. Sassier, B. Bouquet et al (dir.) Les implicites de la politique familiale. Approches historiques, juridiques et politiques (pp. 223-229) Paris: Dunod.

${ }^{9}$ Nota do tradutor: O Front National é um partido de extrema direita francês que sustenta um discurso político xenófobo e advoga uma "França para os franceses", entre outras proposições características da extrema direita.
10 Fassin, E. (2009) Le sexe de l'immigration. In Cette France-là (pp. 108-117). Paris: Association Cette Francelà/La Découverte.

${ }^{11}$ Nota do tradutor: De acordo com Eric Fassin (comunicação pessoal) a lei considera somente o DNA materno para fins de filiação, ao excluir o DNA paterno ela reforça o caráter biológico da filiação.

12 Nota do tradutor: em francês o termo utilizado foi “cavalier législatif”, aqui optei por não traduzir o termo, mas definir seu sentido jurídico como forma de facilitar a leitura.

${ }^{13}$ Ver Borrillo, D., Fassin, E., Mamère, N. \& Mécary, C. (2008, 28 de junho) Homophobie=identité nationale? Tribuna publicada no Le Monde.

${ }^{14}$ Nota do tradutor: a tradução literal seria "sem documentos", trata-se de um movimento de luta pelo direito dos estrangeiros que não possuem os documentos requeridos para a permanência legal na França.

15 Nota do tradutor: Trata-se de uma associação que busca o reconhecimento oficial das uniões de casais binacionais na França.

\section{Referências}

Borrilo, D. e Fassin, E. (2006, 16 de maio) Um chauvinisme matrimonial. Le Monde. 
Borrillo, D. (2009). La vérité biologique contre l'homoparentalité: le statut du beau-parent ou le «PaCS de la filiation». Droit et Société, 72, 259271.

Fassin, E. (2006) Du sacré dans les sociétés démocratiques: le mariage aux États-Unis, la filiation en France. In A. Cadoret, M. Gros, C. Mecary e B. Perrau (dir.) Homoparentalités. Approches scientifiques et politiques. Paris : PUF

Fassin, E. (2008) L'amour du même et l'amour de l'autre: le 'mariage homosexuel' entre famille nationale et question raciale (France- EtatsUnis). In V. Descourtes, M. Digoix, E. Fassin e W. Rault (Orgs.) Mariages et homosexualités dans le monde. L'arrangement des normes familiales. Paris: Édition Autrement

Kahn, S. M. (2007). Les enfants d'Israël. Une approche culturelle de l'assistance médicale à la procréation Paris: L'Harmattan. [Título original : Reproducing Jews: A Cultural Account of Assisted Conception in Israel, Durham, Duke University Press, 2000]

Rabinow, P. (2000) Le déchiffrage du génome. L'aventure française. Paris: Odile Jacob. [Título original: French DNA : Trouble in purgatory,
Chicago, University of Chicago Press, 1999]

Weil, P. (2002) Qu'est-ce qu'un Français? Histoire de la nationalité française depuis la Révolution (pp. 247-249). Paris: B. Grasset.

Werner, D. (2008, maio 12) La gay-guerre. Elle [Disponível em http://www.elle.fr/elle/societe/edito/l a-gay-guerre/(gid)/610713]

Éric Fassin - Sociólogo, Professor da Universidade Paris VIII- Paris, Pesquisador do IRIS-EHESS-Paris. Endereço: Ecole normale supérieure, Département de sciences sociales, 48 boulevard Jourdan 75014 Paris - França. Tél. : 0143136220 / 00 - Fax : 014313 62

E-mail: eric.fassin@gmail.com 